\title{
1 Parameter sensitivity analysis of duplex Stirling coolers
}

6 Abstract Duplex Stirling coolers are external heat-driven regenerative machines that obtain

\author{
J. Y. Hu ${ }^{1,2 *}$, E. C. Luo ${ }^{1,2}$, W. Dai ${ }^{1,2}$, L. M. Zhang ${ }^{1}$ \\ ${ }^{1}$ CAS Key laboratory of Cryogenics, Technical Institute of Physics and \\ Chemistry, Beijing, 100190, China \\ ${ }^{2}$ University of Chinese Academy of Sciences, Beijing, 100039, China
}

\footnotetext{
${ }^{*}$ Corresponding author. jyhu@mail.ipc.ac.cn.
} 
17 configuration for duplex Stirling coolers was also considered, and it showed similar 18 characteristics as the typical configuration.

19 Key words: duplex Stirling; regenerative; parameter sensitivity 20 


\begin{tabular}{|c|c|c|c|}
\hline \multicolumn{4}{|c|}{ Nomenclature } \\
\hline$A_{\text {pis }}$ & piston area $\left(\mathrm{m}^{2}\right)$ & $i$ & $\sqrt{-1}$ \\
\hline$I$ & current $(\mathrm{A})$ & Im & $\begin{array}{l}\text { imaginary part of a complex } \\
\text { number }\end{array}$ \\
\hline$K_{\text {pis }}$ & spring constant $(\mathrm{N} / \mathrm{m})$ & $M_{\text {pis }}$ & piston mass $(\mathrm{kg})$ \\
\hline$P_{e n}$ & $\begin{array}{l}\text { fluctuanting pressure in } \\
\text { engine }(\mathrm{Pa})\end{array}$ & $P_{\text {pis }}$ & $\begin{array}{l}\text { fluctuanting pressure in front of } \\
\text { piston }(\mathrm{Pa})\end{array}$ \\
\hline$P_{r e}$ & $\begin{array}{l}\text { fluctuanting pressure in } \\
\text { refrigerator }(\mathrm{Pa})\end{array}$ & $Q_{c}$ & cooling power (W) \\
\hline$Q_{h}$ & heating power (W) & $\operatorname{Re}$ & real part of a complex number \\
\hline$R_{\text {elec }}$ & electric resistance $(\Omega)$ & $R_{\text {mech }}$ & Mechanical resistance $(\mathrm{kg} / \mathrm{s})$ \\
\hline$T_{c}$ & cooling temperature $(\mathrm{K})$ & $T_{h}$ & heating temperature $(\mathrm{K})$ \\
\hline$T_{r}$ & room temperature $(\mathrm{K})$ & $U_{\text {en }}$ & volume flow rate of engine $\left(\mathrm{m}^{3} / \mathrm{s}\right)$ \\
\hline$U_{\text {pis }}$ & $\begin{array}{l}\text { volume flow rate of piston } \\
\left(\mathrm{m}^{3} / \mathrm{s}\right)\end{array}$ & $U_{r e}$ & $\begin{array}{l}\text { volume flow rate of refrigerator } \\
\left(\mathrm{m}^{3} / \mathrm{s}\right)\end{array}$ \\
\hline$v$ & velocity of piston $(\mathrm{m} / \mathrm{s})$ & $W_{\text {acou }, \text { en }}$ & acoustic work out of engine (W) \\
\hline$W_{\text {acou }, \text { re }}$ & $\begin{array}{l}\text { acoustic work into } \\
\text { refrigerator }(\mathrm{W})\end{array}$ & $W_{\text {dissi }}$, pis & $\begin{array}{l}\text { acoustic work dissipated by the } \\
\text { power piston (W) }\end{array}$ \\
\hline$X_{\text {elec }}$ & $\begin{array}{l}\text { imaginary of electric } \\
\text { impedance }\end{array}$ & $Z_{\text {elec }}$ & $\begin{array}{l}\text { electric impedance of the } \\
\text { alternator }(\Omega)\end{array}$ \\
\hline$Z_{\text {en }}$ & $\begin{array}{l}\text { acoustic impedance of the } \\
\text { engine }(\mathrm{Pa} \cdot \mathrm{s} / \mathrm{m})\end{array}$ & $Z_{\text {mech }}$ & $\begin{array}{l}\text { mechanical impedance of piston } \\
(\mathrm{N} \cdot \mathrm{s} / \mathrm{m})\end{array}$ \\
\hline$Z_{r e}$ & $\begin{array}{l}\text { acoustic impedance of the } \\
\text { refrigerator }(\mathrm{Pa} \cdot \mathrm{s} / \mathrm{m})\end{array}$ & $\eta_{e}$ & exergy efficiency \\
\hline$\tau$ & $\begin{array}{l}\text { transduction coefficient } \\
(\mathrm{N} / \mathrm{A})\end{array}$ & $\omega$ & angular frequency $(\mathrm{rad} / \mathrm{s})$ \\
\hline | | & $\begin{array}{l}\text { magnitude of a complex } \\
\text { number }\end{array}$ & & \\
\hline
\end{tabular}




\section{Introduction}

In heat-driven regenerative coolers, high temperature thermal energy is used to generate cyclic pressure fluctuations in heat engines, which are used to produce cooling in refrigerators. The thermal energy can come from any heat source including concentrated solar energy, combustion of fossil fuels or waste material, or the waste thermal streams of industrial plants or power systems. The ability to use thermal energy to produce refrigeration makes these coolers especially attractive where electrical energy is deficient. One potential application is natural gas liquefaction, which is accomplished by burning part of the gas [1]. At present, the highest reported efficiency of heat-driven regenerative natural gas liquefaction has been achieved by burning about $30 \%$ to liquefy the rest $[2,3]$.

There are three kinds of heat-driven regenerative coolers: the Vuilleumier cooler, the heat-driven thermoacoustic cooler, and the duplex Stirling cooler. In a Vuilleumier cooler, pressure fluctuations are produced by shuttling gas periodically from an ambient temperature region to a high temperature region by the action of a reciprocating displacer in a hot cylinder. There is another displacer in the cold cylinder to pump heat. The hot and cold displacers are coupled by a kinematic mechanism to maintain proper phasing and synchronous operation. The friction between the displacers and the cylinders makes the Vuilleumier cooler susceptible to failure, which limits its application [4]. In a heat-driven thermoacoustic cooler, the engine and refrigerator are coupled acoustically and the pressure fluctuates spontaneously as long as the heating temperature is maintained [5-7]. There are no moving parts, which results in reliability and simplicity. The working frequency of this cooler is determined by the length of the resonant tube [8]. However, the flow loss in the resonant tube is significant, especially when the pressure ratio is high, so the efficiency of the thermoacoustic cooler is low [9]. In a duplex Stirling cooler, a power piston is employed to couple a free-piston engine 
and a free-piston refrigerator. Two displacers are used to adjust the phase [10]. Compared with a heat-driven thermoacoustic cooler, there are no long tubes so the flow loss is significantly reduced. Furthermore, the moving parts are suspended by flexure or gas bearings, which eliminates frictional contact. Therefore a duplex Stirling cooler has the advantages of high efficiency, high reliability, and compactness.

The free-piston Stirling concept was introduced by Beal in 1969 [11]. In recent years, it has drawn worldwide attentions due to the urgent need for renewable energy technologies [12-18]. In the 1980s, several duplex Stirling machines were developed by Sunpower Inc. and while experimental results demonstrated their feasibility, detailed parameters of these machines and quantitative results were not presented [19-21]. With the exception of several analyses [22-25], very little progress regarding duplex Stirling machines has been reported since. Compared with a free-piston engine or cryocooler $[26,27]$, the duplex configuration is more complex, which inevitably increases the difficulty in building such a system. Steady state operation can be achieved only when the acoustic power dissipated by the power piston is equal to the difference between the powers delivered by the engine and absorbed by the refrigerator. This paper will quantify the energy balance and demonstrate how the performance is influenced when system parameters deviate from the designed values. Several methods will be introduced to keep the system working steadily. To find possible ways to avoid parameter sensitivity, a new configuration for the duplex Stirling cooler will be developed. Finally, conclusions will be drawn.

\section{Parameters of the system}

\subsection{Design for the engine and refrigerator}

Fig. 1(a) shows the schematic of a duplex Stirling cooler design, which includes three 
main components: a free-piston Stirling engine, a free-piston Stirling refrigerator, and a power piston between the engine and refrigerator. The designed working frequency is $50 \mathrm{~Hz}$ and the charging pressure is $6 \mathrm{MPa}$. Sharing the same power piston, the engine and the refrigerator have the same swept volume. To ensure the system can work independently, the engine must output more acoustic power than the refrigerator absorbs since the power piston will dissipate some work. So the refrigerator was first designed independently, then the parameters of the engine is adjusted to satisfy this.

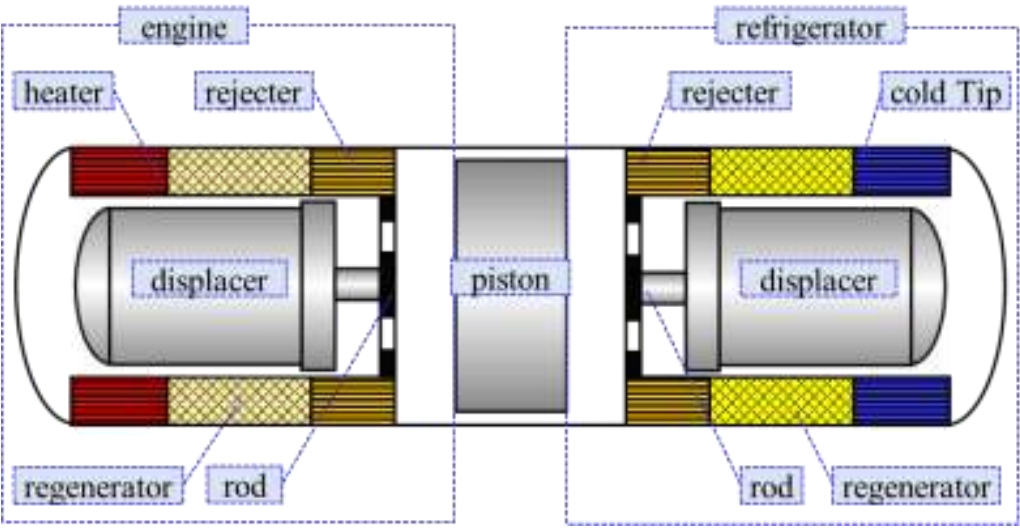

(a)

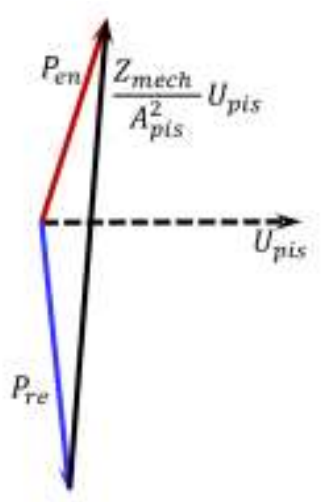

(b)

Figure 1 (a) Schematic of a typical duplex Stirling cooler, (b) phasor diagram of the pressures and volume flow rate

For the refrigerator with the parameters in Table 1, it absorbs an acoustic work $W_{\text {acou, re }}$ of $7247 \mathrm{~W}$ and produces a cooling power $Q_{c}$ of $2043 \mathrm{~W}$ at $110 \mathrm{~K}$, corresponding to a coefficient of performance $\left(Q_{c} / W_{\text {acou }, r e}\right)$ of 0.282 . Its acoustic impedance $Z_{r e}$ is $7.80 \times$ $10^{7} \angle-79.4^{\circ} \mathrm{Pa} . \mathrm{s} / \mathrm{m}$. The swept volume of the power piston is $638 \mathrm{cc}$. Given the diameter and mechanical resistance in Table 1, the piston displacement of $14 \mathrm{~mm}$ and dissipated power $W_{\text {dissi,pis }}$ of $970 \mathrm{~W}$ are obtained. So the engine must output acoustic work $W_{\text {acou,en }}$ of $8217 \mathrm{~W}$. After adjusting, the parameters for the engine are then obtained as shown in Table 1. It absorbs $16.1 \mathrm{~kW}$ heating power $Q_{h}$ at $873 \mathrm{~K}$, corresponding to a thermal efficiency 
overall exergy efficiency is defined as

$$
\eta_{e}=\frac{Q_{c} T_{h}\left(T_{r}-T_{c}\right)}{Q_{h}\left(T_{h}-T_{r}\right) T_{c}}
$$

\begin{tabular}{|c|c|c|}
\hline \multirow{6}{*}{ engine } & $\begin{array}{l}\text { Heat } \\
\text { rejecter }\end{array}$ & Tube-shell type, $80 \mathrm{~mm}$ in length, cooled by water of $300 \mathrm{~K}$ \\
\hline & regenerator & $\begin{array}{l}158 \mathrm{~mm} \text { in diameter and } 70 \mathrm{~mm} \text { in length, filled with random } \\
\text { stainless fiber with diameter of } 16 \mu \mathrm{m} \text { and porosity of } 90 \%\end{array}$ \\
\hline & heater & $\begin{array}{l}\text { composed of } 100 \text { tube with diameter of } 3 \mathrm{~mm} \text { and length of } 300 \\
\mathrm{~mm}\end{array}$ \\
\hline & displacer & $\begin{array}{l}150 \mathrm{~mm} \text { in diameter and } 2 \mathrm{~kg} \text { in weight, with mechanical } \\
\text { resistance of } 30 \mathrm{~kg} / \mathrm{s} \text { and flexure bearing stiffness of } 3 \times 10^{5} \\
\mathrm{~N} / \mathrm{m}\end{array}$ \\
\hline & rod & $47.4 \mathrm{~mm}$ in diameter \\
\hline & $\begin{array}{l}\text { compression } \\
\text { chamber }\end{array}$ & volume of $2.27 \mathrm{~L}$ \\
\hline $\begin{array}{l}\text { power } \\
\text { piston }\end{array}$ & piston & $\begin{array}{l}170 \mathrm{~mm} \text { in diameter } 25 \mathrm{~kg} \text { in weight, with mechanical resistance } \\
\text { of } 100 \mathrm{~kg} / \mathrm{s} \text { and flexure bearing stiffness of } 5.56 \times 10^{4} \mathrm{~N} / \mathrm{m}\end{array}$ \\
\hline \multirow{6}{*}{ refrigerator } & $\begin{array}{l}\text { Heat } \\
\text { rejecter }\end{array}$ & Tube-shell type, $80 \mathrm{~mm}$ in length, cooled by water of $300 \mathrm{~K}$ \\
\hline & regenerator & $\begin{array}{l}180 \mathrm{~mm} \text { in length and } 75 \mathrm{~mm} \text { in diameter, filled with } 300 \text { mesh } \\
\text { stainless screens }\end{array}$ \\
\hline & cold tip & $\begin{array}{l}\text { composed of } 100 \text { tube with diameter of } 3 \mathrm{~mm} \text { and length of } 200 \\
\mathrm{~mm}\end{array}$ \\
\hline & displacer & $\begin{array}{l}140 \mathrm{~mm} \text { in diameter } 2 \mathrm{~kg} \text { in weight, with mechanical resistance } \\
\text { of } 25 \mathrm{~kg} / \mathrm{s} \text { and flexure bearing stiffness of } 2.75 \times 10^{5} \mathrm{~N} / \mathrm{m}\end{array}$ \\
\hline & rod & $37 \mathrm{~mm}$ in diameter \\
\hline & $\begin{array}{l}\text { compression } \\
\text { chamber }\end{array}$ & volume of $1.45 \mathrm{~L}$ \\
\hline
\end{tabular}

the exergy efficiency for this system is $33.3 \%$, which indicates that consuming about $11 \%$ of the gas is sufficient to liquefy the remainder; this is comparable to conventional large-scale liquefiers based on Joule-Thomson or Brayton cycles [28, 29].

Table 1 Parameters of the designed duplex Stirling cooler 
together by the power piston, an energy balance will be built among $W_{\text {acou,en }}, W_{\text {acou, re }}$ and $W_{\text {dissi,pis }}$. In a practical system, many parameters such as the mechanical resistance of the power piston, charging pressure, and heating temperatures, et al may deviate from the designed values, which will destroy the designed energy balance. The system may change its working parameters to reach another balance instead of the designed. $W_{\text {dissi, }}$ is is very small compared $W_{\text {acou,en }}$ and $W_{\text {acou,re }}$. Little change of $W_{\text {acou,en }}-W_{\text {acou,re }}$ may result great change of piston displacement since $W_{\text {dissi, } p i s}$ is a function of piston displacement. So, how the system will respond to the parameter change must be further investigated.

\subsection{Design for the total duplex Stirling cooler}

With the Newton's law for the power piston, there is [31],

$$
P_{e n}-P_{r e}=\frac{Z_{m e c h}}{A_{p i s}^{2}} U_{p i s}
$$

If the phase of $U_{p i s}$ is set to zero, the phasor diagram of the pressures and volume flow rate can be shown as in Fig. 1(b). The pressures in the engine and refrigerator are almost phaseopposite. The purpose of the power piston is to make the phases match. The phase of $Z_{m e c h}$ was very close to $90^{\circ}$. Eq. (2) can be rewritten as

$$
Z_{\text {en }} A_{\text {pis }}^{2}-Z_{r e} A_{\text {pis }}^{2}=Z_{\text {mech }}
$$

Because

$$
Z_{\text {mech }}=R_{\text {mech }}+i\left(\omega M_{p i s}-K_{p i s} / \omega\right),
$$

two equations can be obtained from Eq. (3),

$$
\begin{aligned}
& \operatorname{Re}\left(Z_{e n}\right) A_{p i s}^{2}-\operatorname{Re}\left(Z_{r e}\right) A_{p i s}^{2}=R_{\text {mec } h} \\
& \operatorname{Im}\left(Z_{e n}\right) A_{p i s}^{2}-\operatorname{Im}\left(Z_{r e}\right) A_{p i s}^{2}=\omega M_{p i s}-K_{p i s} / \omega
\end{aligned}
$$

If $\frac{1}{2}|v|^{2}$ is multiplied to Eq. (5), this equation will show the energy balance. The left two 
terms represent the output work of the engine $W_{\text {acou,en }}$ and the absorbed work of the refrigerator $W_{\text {acou }, \text { re }}$, respectively. The right term represents the dissipated work by the power piston $W_{\text {dissi,pis }}$. Eq. (6) shows how to design the piston's mass and spring to make the system to work with a certain frequency. For a given duplex Stirling cooler, if parameters deviate from design, the system will automatically adjust the working frequency and the piston displacement to satisfy the equations.

With Eqs. (5) and (6), the duplex Stirling cooler can be simulated in one numerical programme based on SAGE. Fig. 2 shows the user interface panel of this program. It simulates all parts of the system and numerically determines the values of the working frequency and power piston's displacement to satisfy Eqs. (5) and (6). Therefore, the system performance and sensitivity to a number of system parameters can be investigated with this program.
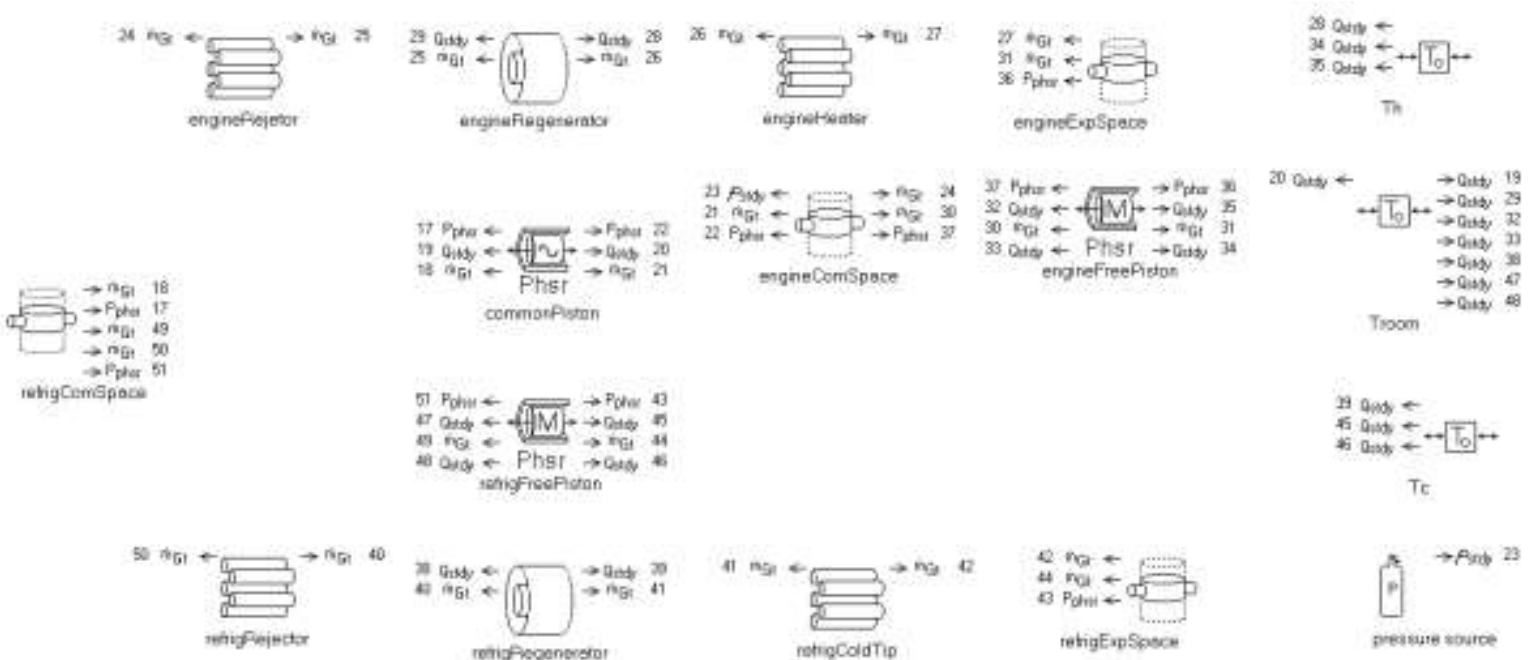

srgineComspoce

engrefreepietor
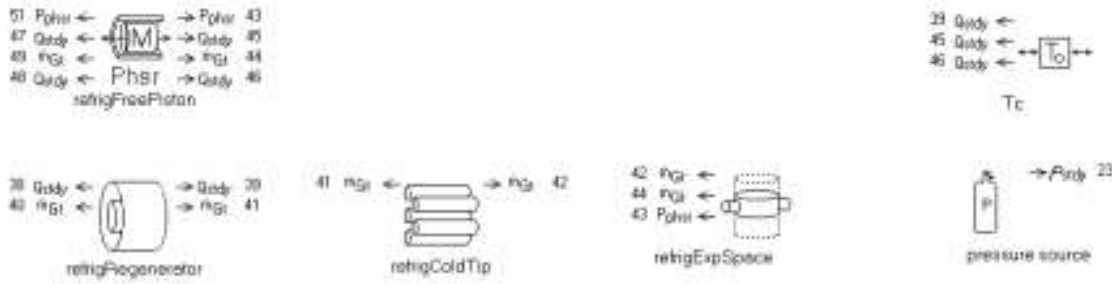

Figure 2 The front panel of the numerical program for the duplex Stirling cooler

\section{Parameter sensitivity}

Because of uncertainties in the machining and assembly accuracy, it is difficult to predict the mechanical resistance of the power piston in the design stage. Its actual value may deviate 
138 from the design. Fig. 3 shows the influence of the power piston's mechanical resistance on the 139 piston displacement and overall exergy efficiency of the system. Changing the mechanical 140 resistance of the power piston disrupted the balance between the output work of the engine, 141 the absorbed work of the refrigerator, and the power dissipation of the piston. The system 142 changed the piston displacement to find a new energy balance. It can be seen in Fig. 3 that the 143 power piston's displacement changed significantly with the mechanical resistance, which 144 resulted in a significant decrease of the heating and cooling power, as shown in Fig. 4. The 145 decrease of piston displacement makes the efficiency of the engine and refrigerator increase 146 slightly, so the exergy efficiency in Fig.3 increases a little bit when the resistance increases 147 from 50 to $100 \mathrm{~kg} / \mathrm{s}$. When the resistance further increases, the output work of the engine 148 decreases very fast and the dissipated work by the piston become a relative big part, so the 149 exergy efficiency decreases a little bit. The sensitivity of the system to the piston's 150 mechanical resistance is a disadvantage because a piston displacement greater than the design 151 limit may destroy the flexure bearings, while a piston displacement less than the design limit will deteriorate the cooling performance. 


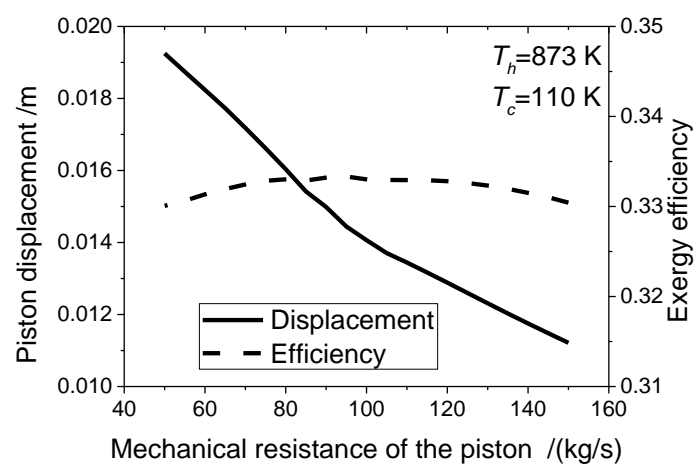

Figure 3 Influence of the power piston's mechanical resistance on the piston displacement and overall exergy efficiency.

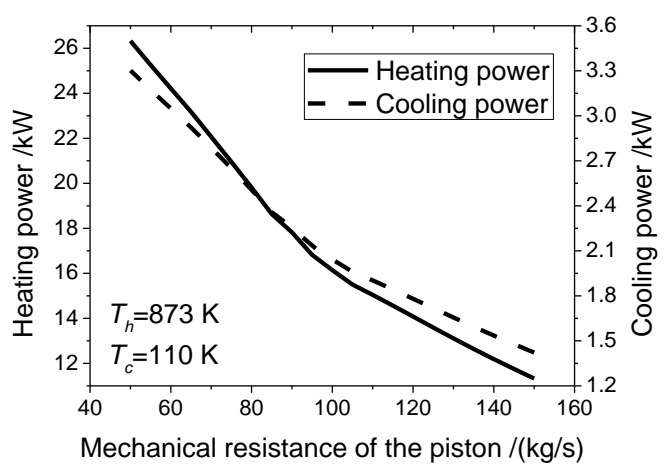

Figure 4 Influence of the power piston's mechanical resistance on the heating and cooling power.
155

156

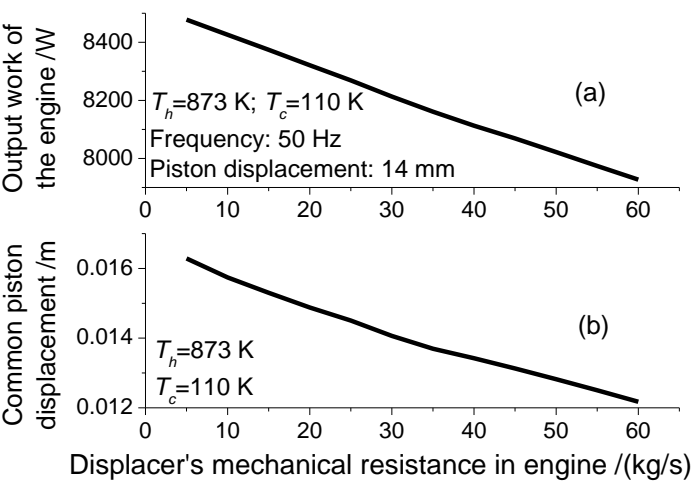

Figure 5 Influence of the displacer's mechanical resistance in the engine on the power piston displacement and output work of the engine.
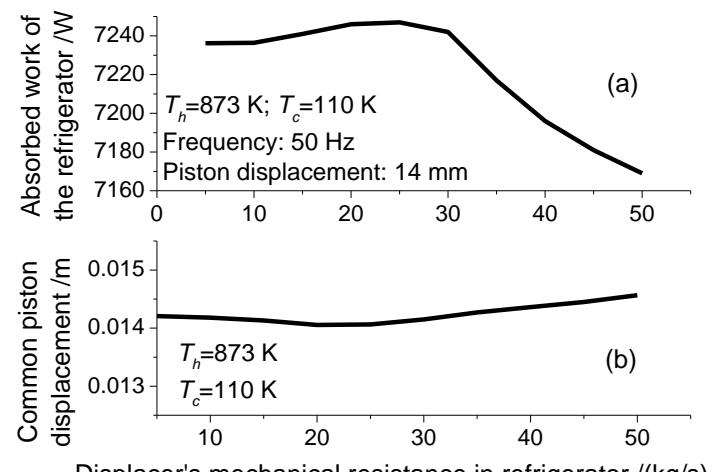

Displacer's mechanical resistance in refrigerator $/(\mathrm{kg} / \mathrm{s})$

Figure 6 Influence of the displacer's mechanical resistance in the refrigerator on the power piston displacement and absorbed work of the refrigerator. $\mathrm{mm}$ and $50 \mathrm{~Hz}$, respectively, it was found that the output work of the engine dropped from

1608478 to $7927 \mathrm{~W}$ if the displacer's mechanical resistance in the engine was increased from 5 to $60 \mathrm{~kg} / \mathrm{s}$ as shown in Fig. 5(a). So, if the displacer's actual resistance deviated from the 
adjust significantly to find the new energy balance as shown in Fig. 5(b). However, as shown in Fig. 6, if the displacer's mechanical resistance in the refrigerator increased from 5 to 50 $\mathrm{kg} / \mathrm{s}$, the work absorbed by the refrigerator varied over a smaller range, from 7169 to $7236 \mathrm{~W}$, so it was not necessary for the piston to change its displacement as much to find the new energy balance in this case.

In a practical system, the heating and cooling temperatures may fluctuate. It was necessary to investigate the influence of the temperatures on the power piston's displacement. In Fig. 7, it can be seen that the piston displacement increased rapidly with increased heating temperature. With the heating temperature $50 \mathrm{~K}$ higher than the designed value, the engine would output more acoustic work, so the piston displacement increased to $20 \mathrm{~mm}$ from 14 $\mathrm{mm}$. At a heating temperature below $570 \mathrm{~K}$, the piston displacement was zero, indicating the system would be nonfunctional. In Fig. 8, it can be seen that the piston displacement was also sensitive to the cooling temperature because the cooling temperature would change the absorbed work of the refrigerator. At a cooling temperature of $300 \mathrm{~K}$, if the heating temperature was lower than $420 \mathrm{~K}$, the engine could not output enough acoustic work, so the piston would not move as shown in Fig. 9. This indicates the onset temperature of this system is greater than $420 \mathrm{~K}$. These results also suggest that the heating temperature should not be high when the cold tip has not been cooled down, otherwise the piston's displacement will exceed the design limit. 


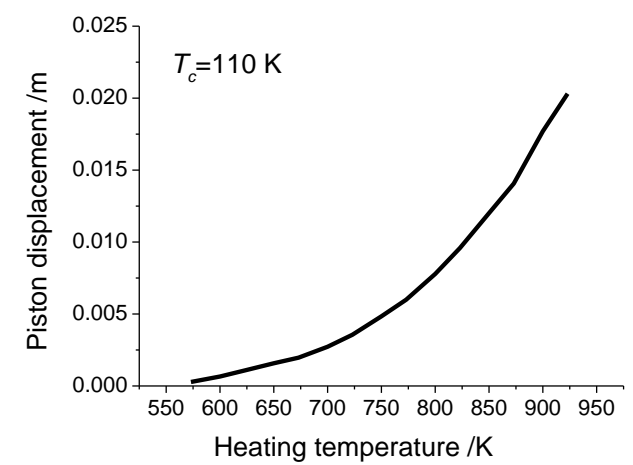

Figure 7 Influence of the heating temperature on the power piston displacement.

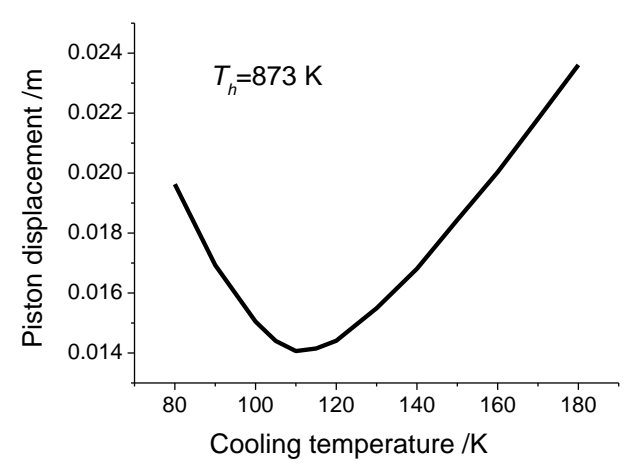

Figure 8 Influence of the cooling temperature on the power piston displacement.

When the working gas was heated or cooled, the average charging pressure of the system changed. Therefore the influence of the system charging pressure on the power piston's motion (displacement and frequency) was also investigated. The results are shown in Fig. 10. Because higher charging pressure is helpful for the engine to output more acoustic work, so it can be seen, the motion of the power piston was sensitive to the charging pressure. 


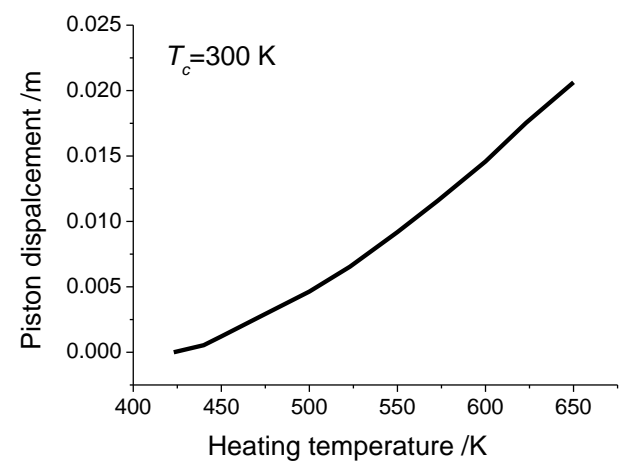

Figure 9 Influence of the heating temperature on the power piston displacement.

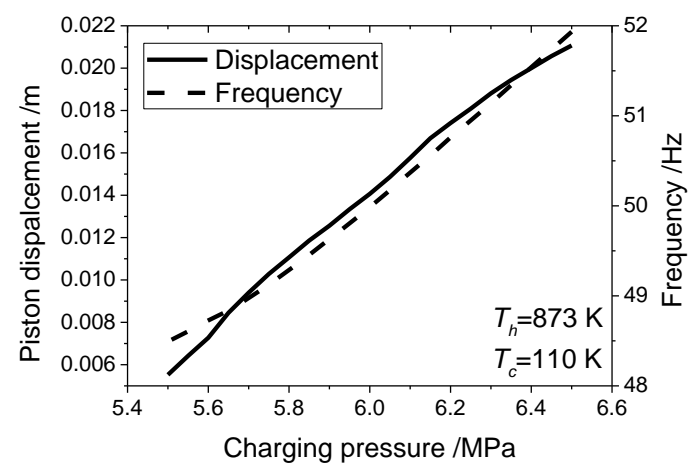

Figure 10 Influence of the charging pressure on the power piston displacement and working frequency.

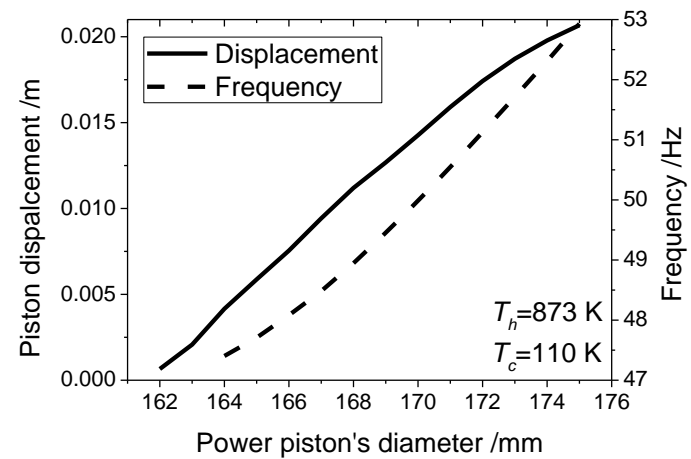

Figure 11 Influence of the power piston's diameter on its displacement and frequency.

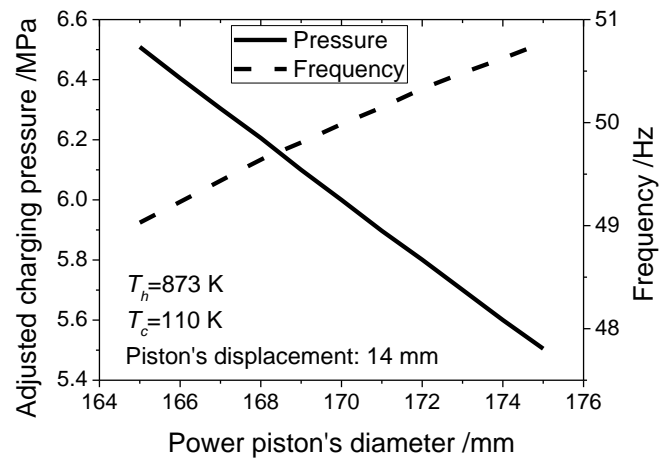

Figure 12 Influence of the power piston's diameter on the charging pressure and working frequency, while holding the piston displacement constant.

Generally, when the diameter changes, the piston displacement would change

199 correspondingly, which would further change the dissipated work. So it can be seen that the piston displacement was sensitive to the diameter. A certain amount of error is inevitable in the simulation of a duplex Stirling cooler because of complications arising from the 
oscillating flow and heat transfer. If the actual phase angle of the refrigerator $Z_{r e}$ was $78.3^{\circ}$ instead of the calculated value of $77.3^{\circ}$ (assuming there is no error with the other parameters), the piston diameter calculated from Eq. (5) was $222 \mathrm{~mm}$. According to the result in Fig. 11, the piston displacement and operating frequency would increase to a point that would put the flexure bearings in extreme stress if this piston were employed.

\section{Methods to keep the displacement constant}

\subsection{Adjusting the charging pressure}

Generally, the working frequency was influenced by the charging pressure and power piston diameter, as seen in Figs. 10 and 11. The working frequency affects the energy balance between the engine, refrigerator, and power piston, which is the main reason that the piston's displacement is influenced by the charging pressure and power piston diameter. Therefore, actively changing the working frequency of the system should allow for a constant piston displacement. For a given system adjusting the charging pressure is easier than adjusting the piston diameter, which is fixed after machining. In Fig. 11, the piston's displacement varied very fast with the piston diameter. By adjusting the charging pressure, the piston displacement could be kept constant at $14 \mathrm{~mm}$ as shown in Fig. 12. If the piston's diameter was less than $170 \mathrm{~mm}$, the charging pressure should be increased. If the piston's diameter was greater than $170 \mathrm{~mm}$, the charging pressure should be decreased. In this way the working frequency was kept close to the desired $50 \mathrm{~Hz}$ value. The corresponding cooling power and exergy efficiency are shown in Fig.13 and remained relatively constant.

If the piston's mechanical resistance deviates from the designed value, adjusting the charging pressure can also ensure the piston displacement remained constant, without significantly reducing the cooling power as shown in Fig. 14. The same method can be 

value.

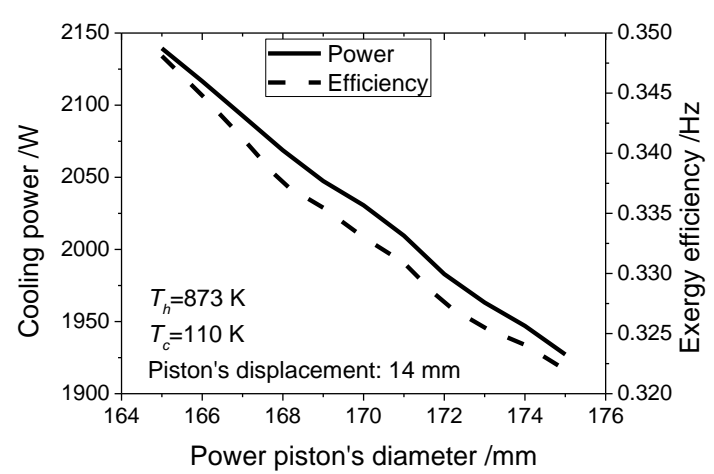

Figure 13 Influence of the power piston's diameter on the cooling power and exergy efficiency, while holding the piston displacement constant.

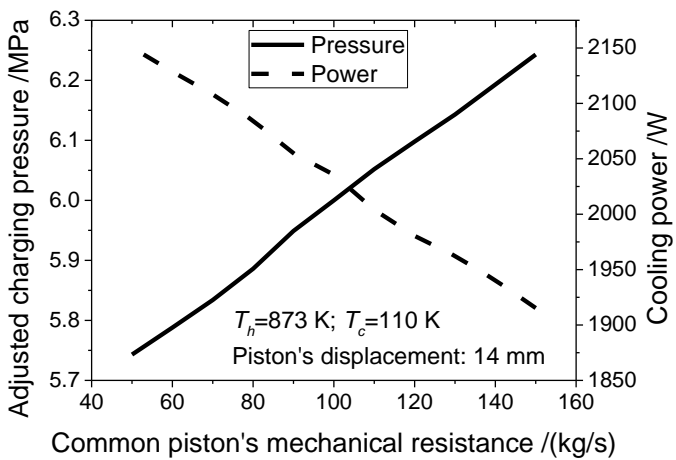

Figure 14 Influence of the power piston's mechanical resistance on the charging pressure and cooling power, while holding the piston displacement constant.

\subsection{Employing a linear alternator}

For instantaneous deviations in the heating and cooling temperatures, it is not possible to piston and alternator,

$$
Z_{e n} A_{p i s}^{2}-Z_{r e} A_{p i s}^{2}=R_{m e c h}+i\left(\omega M_{p i s}-K_{p i s} / \omega\right)+\tau I / v
$$


241 Combining Eqs. (7) and (8),

$$
\begin{aligned}
& \operatorname{Re}\left(Z_{\text {en }}\right) A_{\text {pis }}^{2}-\operatorname{Re}\left(Z_{\text {re }}\right) A_{\text {pis }}^{2}=R_{\text {mec } ~}+R_{\text {elec }} \tau^{2} /\left|Z_{\text {elec }}\right|^{2} \\
& \operatorname{Im}\left(Z_{\text {en }}\right) A_{\text {pis }}^{2}-\operatorname{Im}\left(Z_{\text {re }}\right) A_{\text {pis }}^{2}=\omega M_{\text {pis }}-K_{\text {pis }} / \omega-X_{\text {elec }} \tau^{2} /\left|Z_{\text {elec }}\right|^{2}
\end{aligned}
$$

For simplicity, let $X_{\text {elec }}$ be zero. The program then optimized $R_{\text {elec }}$ and working

245 frequency to satisfy Eqs. (9) and (10).

246

247

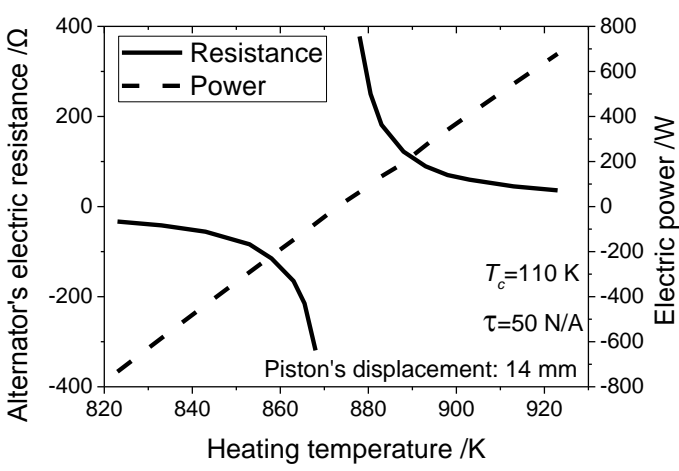

Figure 15 Influence of the heating temperature on the alternator's electrical resistance and power, while holding the piston displacement constant.

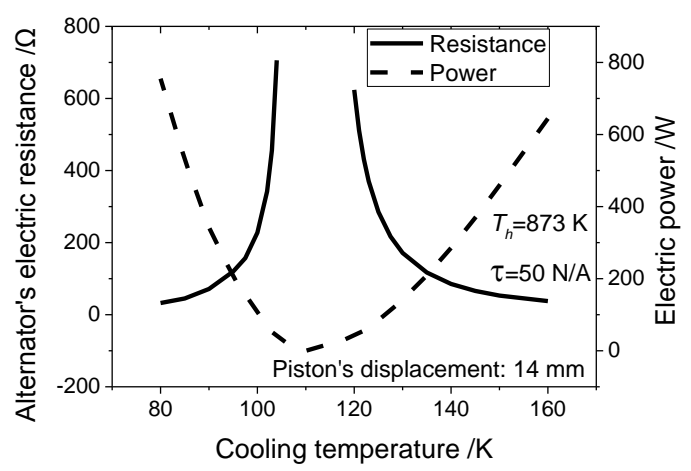

Figure 16 Influence of the cooling temperature on the alternator's electrical resistance and power, while holding the piston displacement constant. 
When the transduction coefficient $\tau$ equaled $50 \mathrm{~N} / \mathrm{A}$, the influence of the heating temperature on the alternator's electric resistance and power is shown in Fig. 15. If the

256 heating temperature was $873 \mathrm{~K}$, the electric resistance was infinite and there was no conversion between acoustic work and electric power. If the heating temperature was higher, the electric resistance was positive, which means the alternator would convert the acoustic work into electric power. If the heating temperature was lower, in theory the alternator could act as a compressor to convert electric power into acoustic work (the negative electric resistance and electric power mean electric power is converted into acoustic work). Of course, it was not necessary as long as the piston displacement was less than the designed value. In Fig. 16, it can be seen that the alternator always converted acoustic work into electric power with high or low cooling temperature if the piston displacement was kept constant.

\section{Discussions about a new configuration}

In the original configuration shown in Fig. 1(a), a single power piston was used, which will induce strong vibrations in the system. Fig. 17(a) shows a new configuration for a duplex Stirling cooler. With the dual-opposed pistons, vibrations induced by the pistons can be avoided. Different from the original, the engine and refrigerator have the fluctuating pressure instead of having the same swept volume. For each piston,

$$
Z_{\text {pis }} A_{\text {pis }}^{2}=Z_{\text {mech }}
$$

With the law of mass conservation,

$$
U_{e n}=U_{r e}+2 U_{p i s}
$$

274 Combining them, we have

$$
U_{e n}=U_{r e}+\frac{2 P_{p i s} A_{p i s}^{2}}{Z_{\text {mec } h}}
$$

Eq. (13) can also be written as 


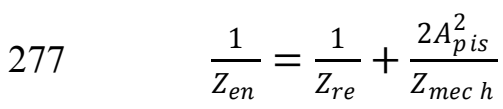

278 If the phase of $P_{p i s}$ is zero, the phasor diagram of the pressure and volume flow rates can be

279 shown as in Fig. 17(b). The volume flow rates in the engine and refrigerator were almost 280 phase-opposite. The purpose of the power piston is to make the volume flow rates match. The 281 phase of $Z_{\text {mec } h}$ was very close to $90^{\circ}$. Fig. 17 (b) also tells that the total swept volume of the 282 two pistons is almost twice of that in the original configuration. Two equations can be 283 obtained from Eq. (11), overall exergy efficiency of $30.6 \%$. If the charging pressure is optimized, the efficiency could be as high as the efficiency of the original configuration shown in Fig. 1(a). This proves that the new configuration is theoretically feasible.

Although the advantage of the dual-opposed pistons is cancellation of the system vibration, it was found that the new configuration had the same parameter sensitivity as the single piston configuration. Adjusting the charging pressure and employing a linear alternator can ensure the system performs at a steady state. 

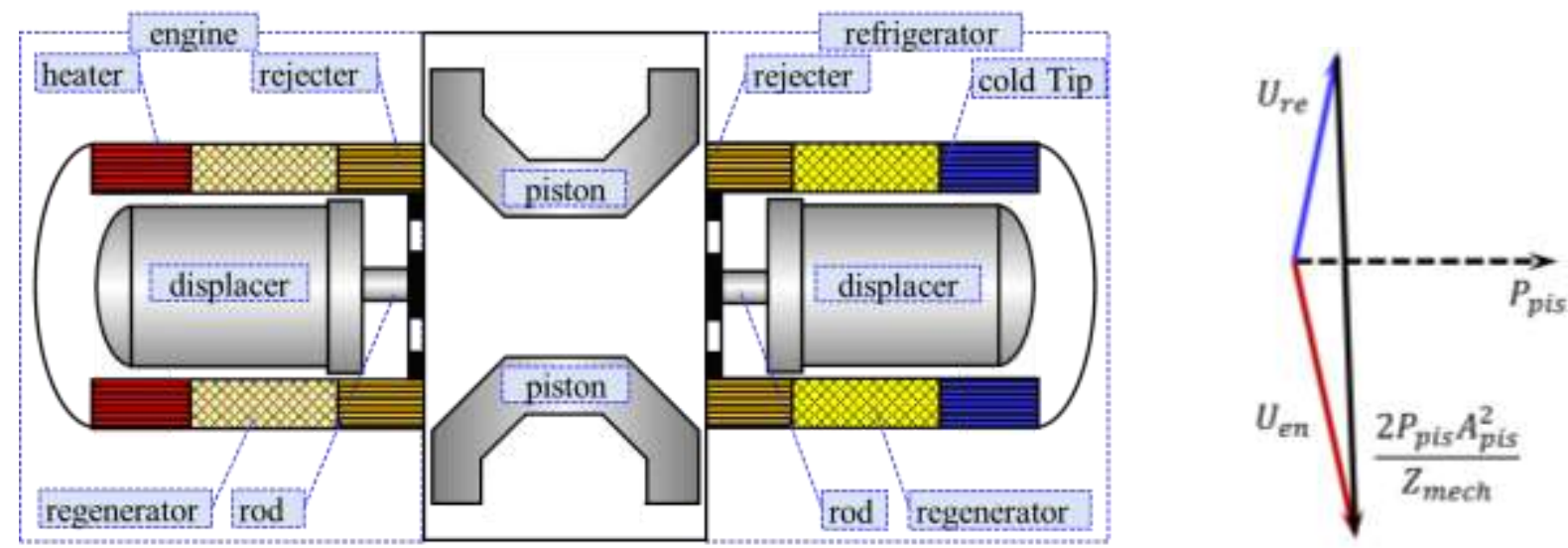

Figure 17 (a) Schematic of a new duplex Stirling cooler, (b) phasor diagram of the pressure and volume flow rates

\section{Conclusion and discussion}

In a duplex Stirling cooler, steady state operation can be achieved only when the acoustic power dissipated by the power piston is equal to the difference between the powers delivered by the engine and absorbed by the refrigerator. This study finds that the system's performance is sensitive to a number of parameters such as the mechanical resistance of the piston, the heating temperature, and the piston diameter. Small variations in these parameters cause the power piston's displacement to deviate significantly from the designed value, which will subsequently alter the working state of the engine and refrigerator. Therefore, in practice the system often operates with an unexpected performance, which may be the main obstacle to build and utilize such a system.

To make the power piston's displacement constant, two methods were presented. First, the system's working frequency varies with the charging pressure; therefore it was shown that changing the charging pressure could help the system offset the influence of variations in system parameters. Second, by converting energy between acoustic work and electric power,

314 a linear alternator can also ensure that the power piston's displacement remains constant, 
especially when the parameters are instantaneously changed. These methods may endow the duplex Stirling cooler with reliable performance outcomes.

A new configuration for duplex Stirling coolers with two dual-opposed pistons was presented. It has the same system parameter sensitivity as the single piston configuration. Adjusting the charging pressure and employing a linear alternator are also applicable methods to keep the power pistons displacement constant in this system.

In this paper, the analyses are conducted in a way by individually investigating the parameter influence while fixing all the other parameters. In real applications, it is more common that several parameters deviate from the designed values, which will make the system more difficult to reach a steady state. But the mechanism of multi-parameter influence is the same as the single parameter. The influence can also be obtained with this method.

\section{Acknowledgements} 51576204 and 51627809) and the Natural Key Research and Development Program (Contract No. 2016YFB0901403).

\section{References}

[1] Walker G, Senft JR. Free piston Stirling engines. Berlin, Germany: Springer-Verlag Berlin and Heidelberg GmbH \& Co. KG, 1985.

[2] Zhang LM, Hu JY, Wu ZH, et al. A 1 kW-class multi-stage heat-driven thermoacoustic cryocooler system operating at liquefied natural gas temperature range. Appl Phys Lett. 2015; 107 (3): 033905.

[3] Xu JY, Zhang LM, Hu JY, et al. An efficient looped multiple-stage thermoacoustically-driven cryocooler for liquefaction and recondensation of natural gas. Energy. 2016; 101: 427-433.

337 [4] Walker G. Cryocoolers. New York: Plenum Press, 1983.

338 [5] Backhaus S, Swift GW. A thermoacoustic Stirling heat engine. Nature. 1999; 399 (6734): 335-338.

339 [6] Tang K, Feng Y, Jin SH, et al. Performance comparison of jet pumps with rectangular and 
circular tapered channels for a loop-structured traveling-wave thermoacoustic engine. Appl Energ. 2015; 148: 305-313.

[7] Wang K, Sun DM, Zhang J, et al. Operating characteristics and performance improvements of a 500 W traveling-wave thermoacoustic electric generator. Appl Energ. 2015; 160: 853-862.

[8] Swift GW. Thermoacoustics: A unifying perspective for some engines and refrigerators. Sewickley PA: ASA Publication, 2002.

[9] Hu JY, Luo EC, Li SF, et al. Heat-driven thermoacoustic cryocooler operating at liquid hydrogen temperature with a unique coupler. J Appl Phys. 2008; 103 (10): 104906.

[10] Penswick B, Urieli I. Duplex Stirling machines. Proc of the 19th Intersociety Energy Conversion Engineering Conference. San Francisco, California, 1984. 1823-1828.

[11] Beale WT. Free piston Stirling engines - some model tests and simulations. Society of Automotive Engineers Congress. Detroit, Michigan, 1969. Paper No. 690230.

[12] Boucher J, Lanzetta F, Nika P. Optimization of a dual free piston Stirling engine. Appl Therm Eng. 2007; 27 (4): 802-811.

[13] Yang Q, Luo EC, Dai W, et al. Thermoacoustic model of a modified free piston Stirling engine with a thermal buffer tube. Appl Energ. 2012; 90 (1): 266-270.

[14] Wu W, Hu JB, Yuan SH. Semi-analytical modelling of a hydraulic free-piston engine. Appl Energ. $2014 ; 120: 75-84$

[15] Wang K, Dubey S, Hoong F, et al. A transient one-dimensional numerical model for kinetic Stirling engine. Appl Energ. 2016; 183: 775-790.

[16] Jia B, Smallbone A, Feng H, et al. A fast response free-piston engine generator numerical model for control applications. Appl Energ. 2016; 162: 321-329.

[17] Tavakolpour-Saleh AR, Zare S, Omidvar A. Applying perturbation technique to analysis of a free piston Stirling engine possessing nonlinear springs. Appl Energ. 2016; 183: 526-541.

[18] Wang K, Sanders SR, Dubey S, et al. Stirling cycle engines for recovering low and moderate temperature heat: A review. Renew Sust Energ Rev. 2016; 62: 89-108.

[19] Berchowitz DM. The design, development and performance of a duplex Stirling natural gas liquefier. 
[20] Gedeon D, Penswick B, Beale W. Duplex Stirling heating - only gas fired heat pump - phase II, final report, Gas Research Institute, 1983.

[21] Urieli I. The design and development of a gas fired free-piston duplex Stirling cooler for home appliances. Proc of 11th Energy Technology Conference. Washington DC, 1984. 610-618.

[22] Walker G, R. F, Gustafson R, et al. Stirling engine heat pumps. Cryogenics. 1982; 5 (2): 91-97.

[23] Berchowitz DM, Shonder J. Estimated size and performance of a natural gas fired duplex Stirling for domestic refrigeration applications. Proc of the 18th International Congress of refrigeration. Montreal,

[24] Chen G, Beale W. Thermally actuated duplex free-piston Stirling system for domestic cooling and heating applications. International Conference on CFCs and Halon Alternatives. Beijing, China, 1993.

[25] Dyson RW, Schmitz PG, Penswick LB, et al. Long-Lived Venus Lander Conceptual Design: How to Keep It Cool. 7th International Energy Conversion Engineering Conference. Denver, CO, 2009.

[26] Tavakolpour-Saleh AR, Zare S, Omidvar A. Applying perturbation technique to analysis of a free piston Stirling engine possessing nonlinear springs. Appl Energ. 2016; 183: 526-541.

[27] Yang Q, Luo EC, Dai W, et al. Thermoacoustic model of a modified free piston Stirling engine with a thermal buffer tube. Appl Energ. 2012; 90: 266-270.

[28] Mokhatab S, Mak JY, Valappil JV, et al. Handbook of Liquefied Natural Gas. 1st Edition. Oxford: Gulf Professional Publishing, 2013.

[29] Hu JY, Chen S, Zhu J, et al. An Efficient Pulse Tube Cryocooler for BOG Reliquefaction in LNG Tanks, Appl Energ. 2016; 164: 1012-1018.

[30] Gedeon D. Sage user's guide, Stirling, pulse-tube and low-T cooler model classes. 10th edition. Athens, OH: Gedeon Associates, 2014.

[31] Hu JY, Luo EC, Zhang LM, et al. A double-acting thermoacoustic cryocooler for high temperature superconducting electric power grids. Appl Energ. 2013; 112: 1166-1170. 